\title{
PRELIMINARY STRATIGRAPHY AND FACIES ANALYSIS OF THE UPPER CRETACEOUS KAGUYAK FORMATION, INCLUDING A BRIEF SUMMARY OF NEWLY DISCOVERED OIL STAIN, UPPER ALASKA PENINSULA
} by

Marwan A. Wartes ${ }^{1}$, Paul L. Decker ${ }^{2}$, Richard G. Stanley ${ }^{3}$, Trystan M. Herriott ${ }^{1}$, Kenneth P. Helmold $^{2}$, and Robert J. Gillis ${ }^{1}$

The Alaska Division of Geological and Geophysical Surveys has an ongoing program aimed at evaluating the Mesozoic forearc stratigraphy, structure, and petroleum systems of lower Cook Inlet. Most of our field studies have focused on the Jurassic component of the petroleum system (this report). However, in late July and early August of 2012, we initiated a study of the stratigraphy and reservoir potential of the Upper Cretaceous Kaguyak Formation.

The Kaguyak Formation is locally well exposed on the upper Alaska Peninsula (fig. 25) and was named by Keller and Reiser (1959) for a sequence of interbedded siltstone and sandstone of upper Campanian to Maastrichtian age that they estimated to be 1,450 m thick. Subsequent work by Detterman and Miller (1985) examined $900 \mathrm{~m}$ of section and interpreted the unit as the record of a prograding submarine fan. This interpretation of deep-water deposition contrasts with other Upper Cretaceous rocks exposed along the Alaska Peninsula and lower Cook Inlet that are generally described as nonmarine to shallow marine (Detterman and others, 1996; LePain and others, 2012). Based on foraminifera and palynomorphs from the COST No. 1 well, Magoon (1986) concluded that the Upper Cretaceous rocks were deposited in a variety of water depths and environments ranging from upper bathyal to nonmarine. During our recent fieldwork west and south of Fourpeaked Mountain, we similarly encountered markedly varying lithofacies in the Kaguyak Formation (fig. 25), and we also found oil-stained rocks that are consistent with the existence of an active petroleum system in Upper Cretaceous rocks on the upper Alaska Peninsula and in lower Cook Inlet. These field observations are summarized below.

\section{Type Section}

The most completely exposed section of Kaguyak stratigraphy crops out along coastal cliffs near Swikshak Lagoon (fig. 25; Keller and Reiser, 1959; Detterman and Miller, 1985). We conducted reconnaissance traverses of the entire eastdipping type section as well as a narrow peninsula approximately $5 \mathrm{~km}$ to the south that is mapped as the lower part of the Kaguyak Formation (Riehle and others, 1993; fig. 25). We subsequently focused our efforts on measuring two detailed stratigraphic sections from the unit's type section - a $75 \mathrm{~m}$ section in the middle of the unit and another $210 \mathrm{~m}$ section capturing the uppermost part of the formation (see fig. 25 for location of sections). For reservoir quality and provenance data, we collected a comprehensive suite of samples tied to these sections. Final reports summarizing the stratigraphic and analytical work are in progress; below is a preliminary summary of our observations and interpretations.

The lowermost stratigraphy exposed at the type section and in neighboring outcrops is dominated by dark-gray-weathering, medium- to thick-bedded, very-fine-grained sandstone and lesser siltstone. Ovoid tan-weathering calcareous concretions are locally common and help define bedding. We observed numerous fossils, including small pelecypods, inoceramids, and ammonites. This part of the unit notably included a diverse and abundant trace fossil assemblage, including possible Helminthopsis or Phycosiphon, Schaubcylindrichnus, Terebellina, Teichichnus, and Thalassinoides (fig. 26). Primary sedimentary structures are rare, likely reflecting a combination of deposition below wave base and thorough disruption of lamination by bioturbation. We interpret this part of the unit as offshore transition to shelfal.

Both detailed measured sections along the coast west of Swikshak Lagoon are notably different than the basal part of the formation and are dominated by a well bedded, rhythmic stratigraphy of alternating siltstone and very-fine- to medium-grained sandstone (fig. 27). Spherical to ovoid calcareous concretions are common and locally reach several meters in diameter. Individual sandstone units commonly exhibit partial Bouma sequences with a sharp base overlain by an upward-fining massive to plane laminated zone that is typically capped by a rippled facies (fig. 28). Sandstone beds locally amalgamate to form bedsets up to $10 \mathrm{~m}$ thick, although 10-40-cm-thick beds separated by thin, recessive mudstone are more common. Evidence for sediment instability is common and includes convolute lamination, load marks, flame and ball and pillow structures, and sandstone dikes. Sole marks are locally abundant and are typically bidirectional grooves; rare flutes and longitudinal scours suggest dominantly east-directed sediment transport. Most beds are very tabular and laterally continuous, although one 8-m-thick zone of highly disrupted and discontinuous bedding suggests the development of a mass transport complex or similar gravitational slumping (fig. 27). Fossils are conspicuously rare, although Inoceramus prism fragments and ammonite debris were observed. Trace fossils and bioturbation are also uncommon in the type section, although we did observe one excellent example of tiered Rhizocorallium (fig. 28). The totality of sedimentary facies is consistent with deposition via sediment gravity flows, ranging from high-density flows to more dilute, turbulent flows. Based on the sedimentary facies, the lack of wave-generated structures, and the dearth of bioturbation, we interpret the upper half of the

\footnotetext{
${ }^{1}$ Alaska Division of Geological \& Geophysical Surveys, 3354 College Rd., Fairbanks, AK 97709-3707

${ }^{2}$ Alaska Division of Oil \& Gas, 550 W. 7th Ave., Suite 800, Anchorage, AK 99501-3560

${ }^{3}$ U.S. Geological Survey, 345 Middlefield Road Mail Stop 969, Menlo Park CA 94025-3561
} 
type Kaguyak Formation as deposited in deep water, beyond the shelf edge. The abundance of sandstone favors deposition in a high-accommodation, high-sediment delivery zone such as the base of slope or basin floor, although it is possible that part of the section represents slope facies. The parts of the section with thick amalgamated sandstone packages may reflect low-stand deposition when abundant coarse-grained material is exported off the shelf.

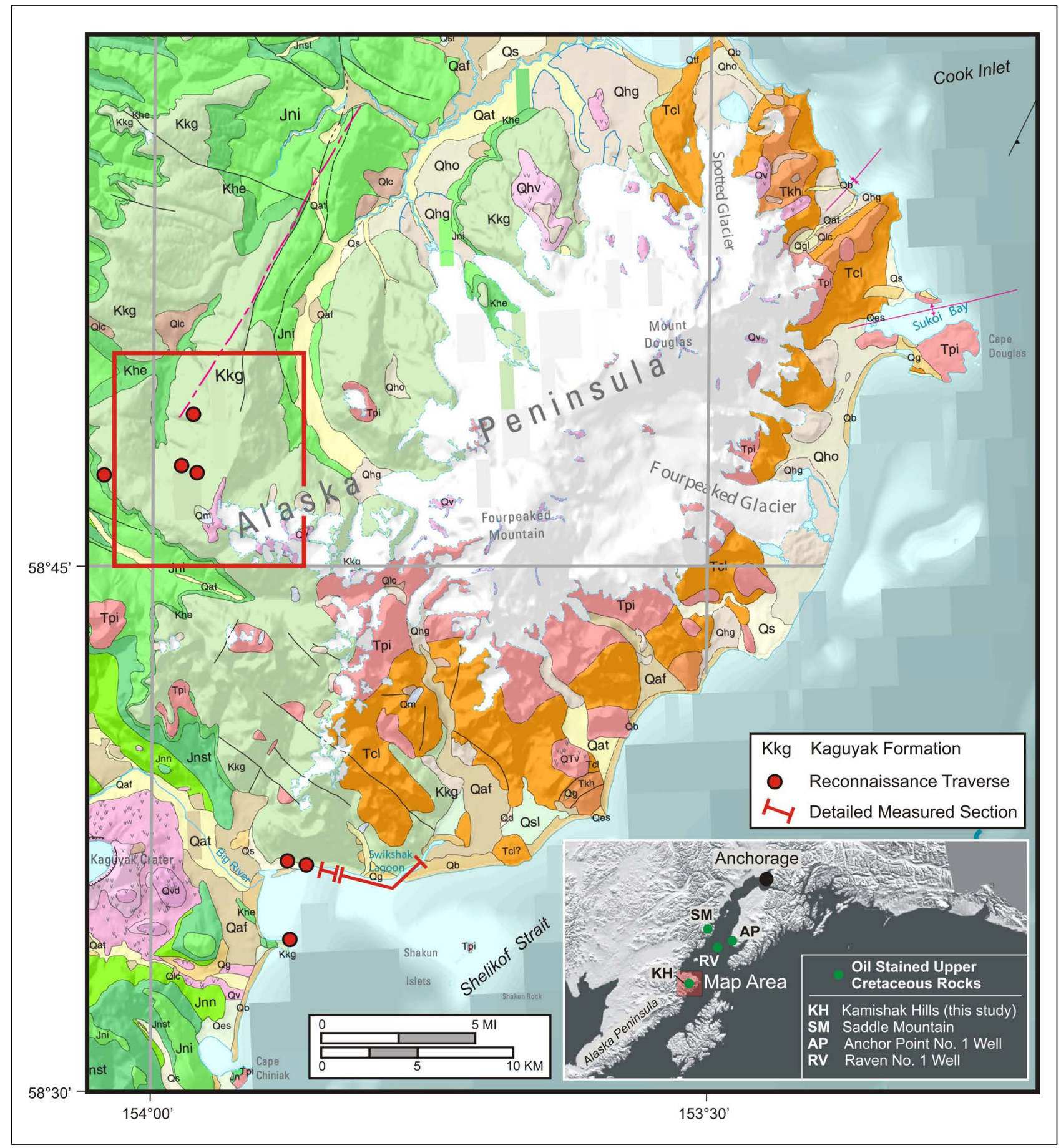

Figure 25. Geologic map of the upper Alaska Peninsula (modified from Wilson and others, 2009), showing the Kaguyak Formation localities inspected in 2012. The red box outlines the location for figure 29 in the eastern Kamishak Hills. Inset map highlights generalized locations of reported oil staining in outcrop, and wells with significant oil shows. 

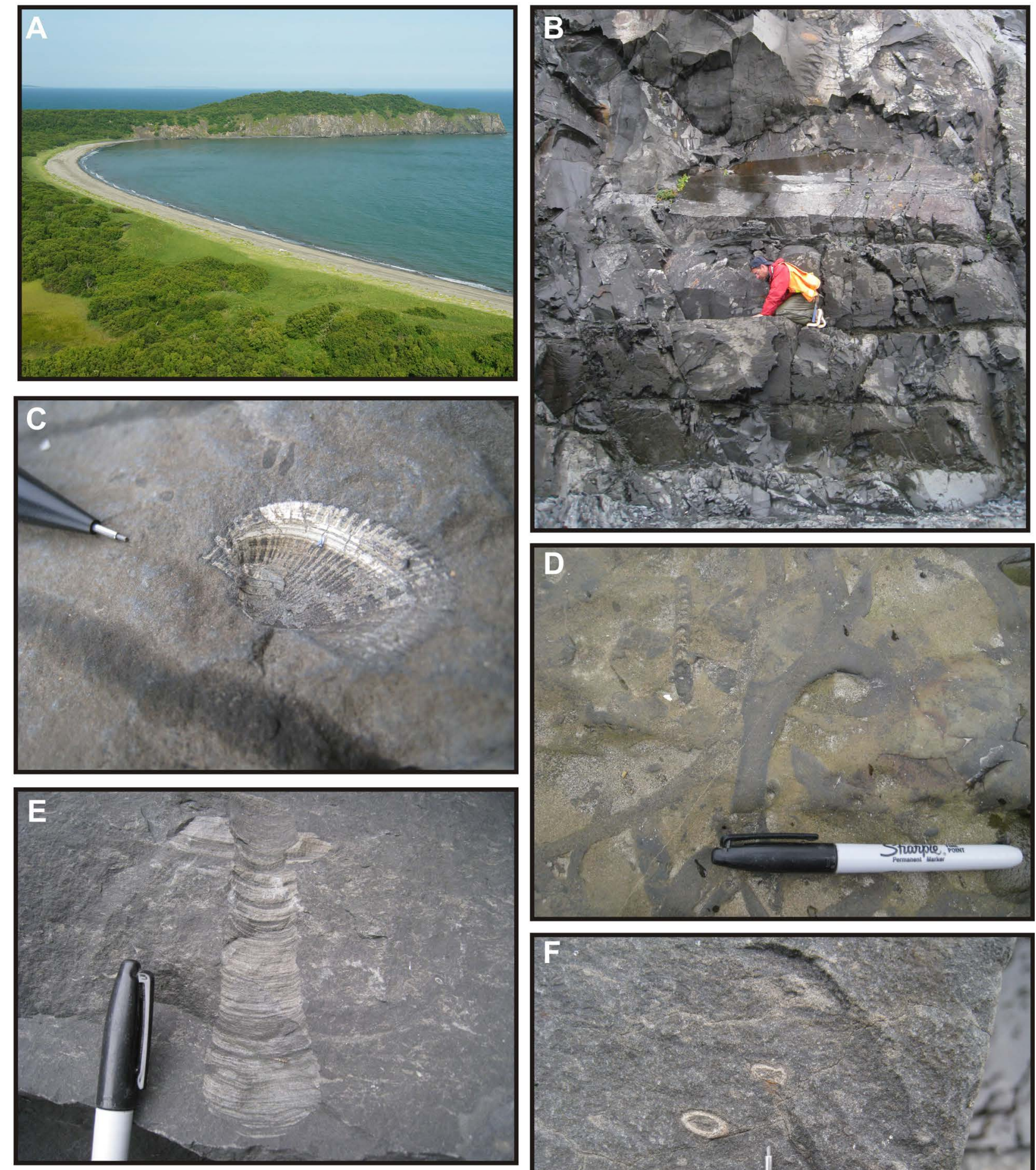

Figure 26. Representative photos of the lower Kaguyak Formation. (A) A narrow peninsula south of the type section that exposes the lowermost part of the formation; (B) example of medium- to thick-bedded, massive, very-fine-grained sandstone; $(C)$ small bivalve; (D) Thalassinoides burrows; (E) Teichichnus burrow;

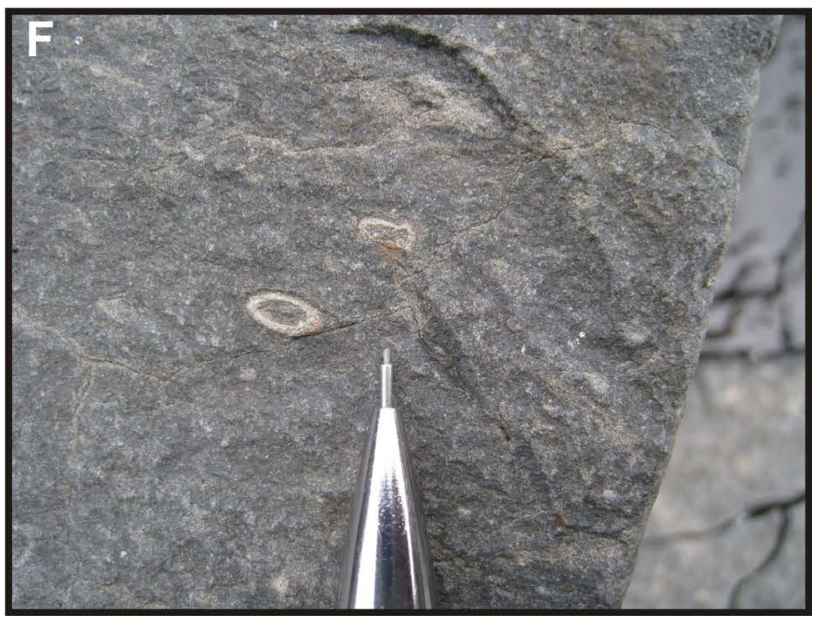
(F) Schaubcylindrichnus trace fossil. 

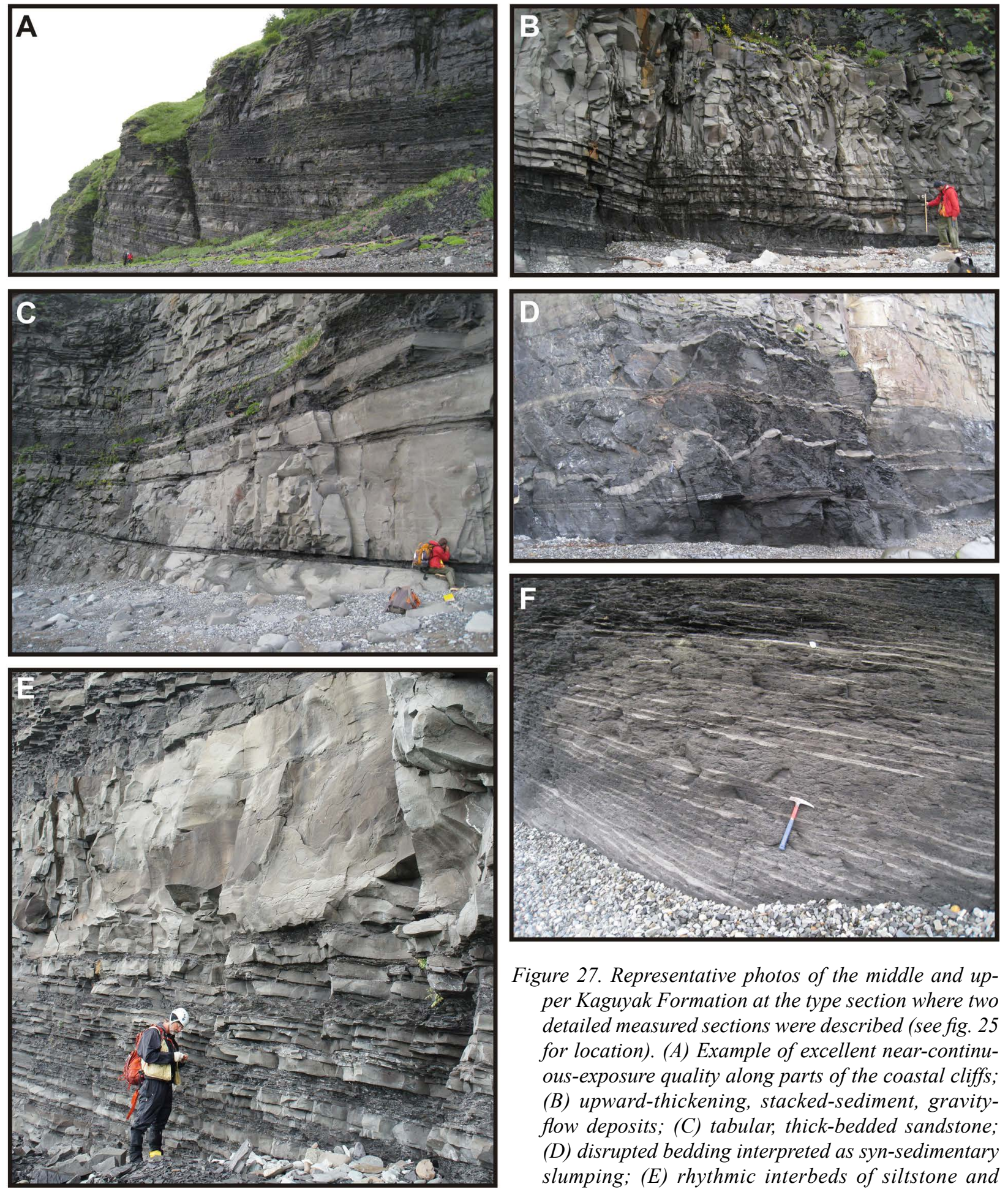

Figure 27. Representative photos of the middle and upper Kaguyak Formation at the type section where two detailed measured sections were described (see fig. 25 for location). (A) Example of excellent near-continuous-exposure quality along parts of the coastal cliffs; (B) upward-thickening, stacked-sediment, gravityflow deposits; (C) tabular, thick-bedded sandstone; (D) disrupted bedding interpreted as syn-sedimentary slumping; (E) rhythmic interbeds of siltstone and very-fine-grained sandstone overlain by a thick, amalgamated fine-grained sandstone bed; $(F)$ example of heterolithic facies comprising siltstone and very-thinbedded, rippled, very-fine-grained sandstone. 

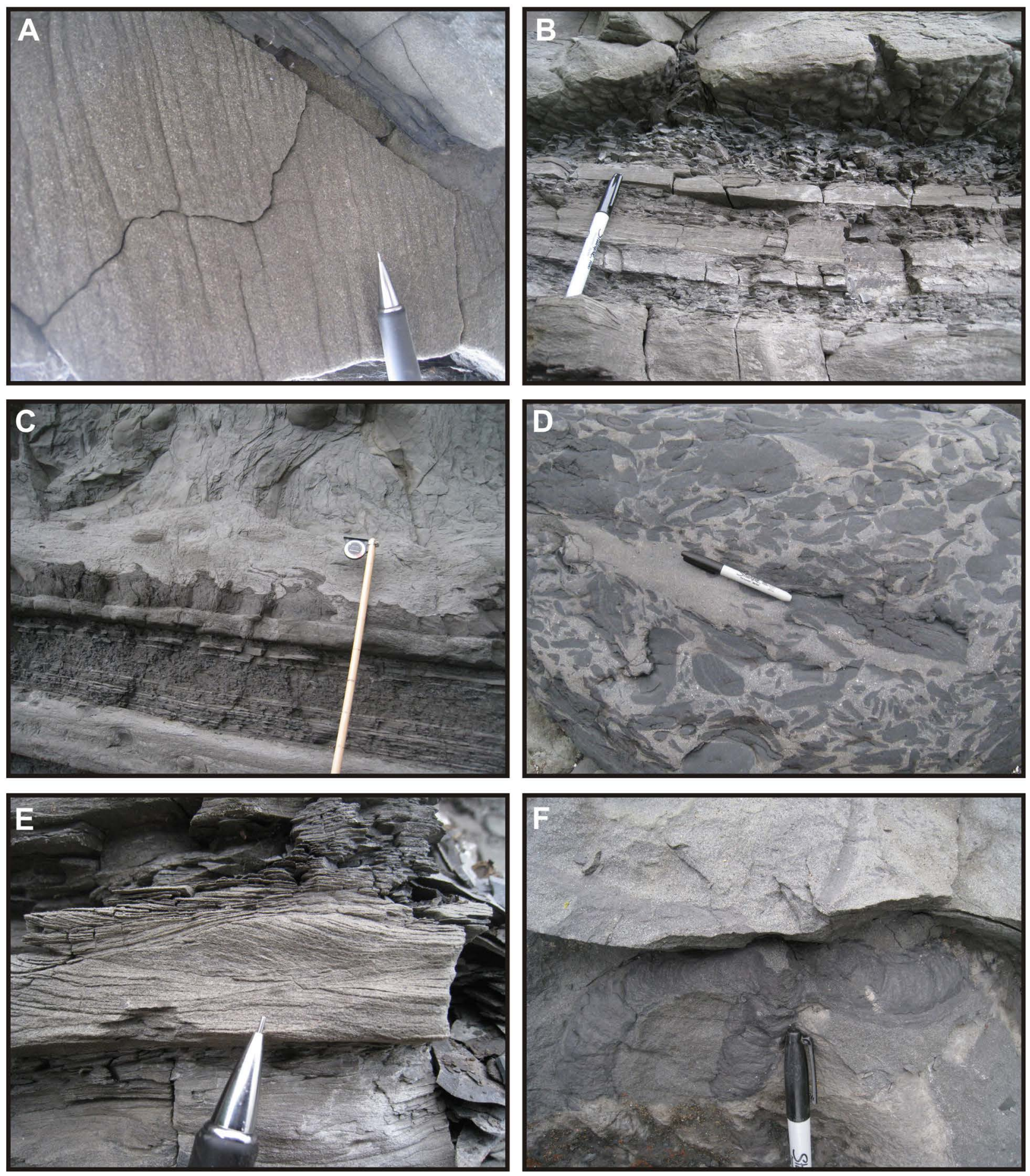

Figure 28. Representative photos of sedimentary structures and facies from measured sections of the middle and upper Kaguyak Formation at its type locality (see fig. 25 for location). (A) Longitudinal scour sole marks provide paleocurrent information; (B) load marks along the base of the sandstone at photo top; (C) flame structures; (D) intraformational mud rip-up conglomerate; (E) climbing ripple cross lamination; $(F)$ unusual Rhizocorralium burrow showing tiered, propeller-shaped structure with branches projecting from a central shaft. 


\section{Kamishak Hills Reconnaissance}

We spent part of two days examining exposures mapped as Kaguyak Formation in the Kamishak Hills (fig. 25; Riehle and others, 1993; see also Jones and Detterman, 1966). Outcrop is extensive, but most of the well exposed sections are extremely steep and inaccessible. Dense vegetation and deep, narrow gorges limited helicopter landings near outcrops. Nevertheless, we examined several outcrops that were distinctly different than the type section of the Kaguyak Formation described above. We did not observe any features that suggested sediment gravity flows. Instead, the rocks included abundant evidence for shelfal water depths, including thick sections of bioturbated siltstone and very fine sandstone and discrete traces such as Paleophycos, Thalassinoides, Planolites, and possible Terrebellina. Inoceramids are locally abundant, as is coalified woody debris. A fairly well exposed channel with $1.5 \mathrm{~m}$ of visible erosional relief and filled with $2.5 \mathrm{~m}$ very-fine- to fine-grained argillaceous sandstone may record an episode of lowered base level and delivery of sediment to the outer shelf or deeper environments.

\section{Hydrocarbon Occurrence}

During a reconnaissance traverse along an unnamed tributary of the Douglas River (fig. 29), we discovered abundant cobbles and small boulders of sandstone in the modern stream gravel that were strongly petroliferous, particularly on freshly broken surfaces (fig. 30). The oil-stained float blocks were dominantly very-fine- to fine-grained sandstone and weather light gray to tan and light greenish-gray. The oil stain occurred as both matrix and fracture fill, with the latter commonly healed. One small boulder of porphyritic andesite was also strongly oil stained along a fracture plane and included visible hydrocarbon within a small vug. The sandstone is dissimilar to the nearby outcrops of Lower Cretaceous Herendeen Formation, and we infer that the clasts were sourced from outcrops of the overlying gently east-southeast-dipping Kaguyak Formation exposed immediately upstream to the east and south. We spent most of one day attempting to locate the origin of these clasts, but were not successful, in part due to the rugged terrain. However, select observations throughout the unit allowed us to reasonably constrain the source of the oil-stained sandstone to a zone within the lower Kaguyak (fig. 29). Several oil-stained samples were collected and will be analyzed for reservoir quality, petrology, and organic geochemistry; results will be published when the analytical data become available.

\section{Summary}

Initial examination of the Kaguyak Formation confirms some of the prior interpretations for this unit, particularly the deep-water depositional environment emphasized by previous workers (Detterman and Miller, 1985). However, our preliminary observations from the type section suggest that the lower part of the formation was likely deposited on the shelf and subsequently witnessed a relative deepening sufficient to transition into basin floor, sediment gravity flow-dominated deposition for the remainder of the unit. Future work will aim to evaluate the cause and regional significance of this stratigraphic change.

The lack of evidence for deep-water deposition in the Kamishak Hills suggests this area may have been more proximal than the type section further southeast. This conclusion is broadly consistent with our preliminary paleocurrent data and suggests the axis of the basin developed east or southeast of the present outcrop belt (see also Hastings and others, 1983; Magoon, 1986). However, additional work is required to better constrain the paleogeography of the Late Cretaceous forearc basin.

The newly discovered oil-stained sandstone cobbles and boulders from the Kaguyak Formation indicate that the unit can preserve sufficient porosity and permeability to serve as an oil reservoir and that viable migration pathways must, at least locally, connect with probable source rocks of the Middle Jurassic Tuxedni Group. Significant oil staining has also been documented elsewhere in Upper Cretaceous rocks in lower Cook Inlet (see inset map in figure 25), such as the nonmarine facies near Saddle Mountain (LePain and others, 2012; Magoon and others, 1980) and reported oil shows in the Raven No. 1 well (LePain and others, 2012) and the Anchor Point No. 1 well (unpublished industry reports). These widespread occurrences in lower Cook Inlet suggest that Upper Cretaceous rocks overlie a regionally extensive, mature, oil-generating source rock and represent a viable oil exploration target in Cook Inlet. 


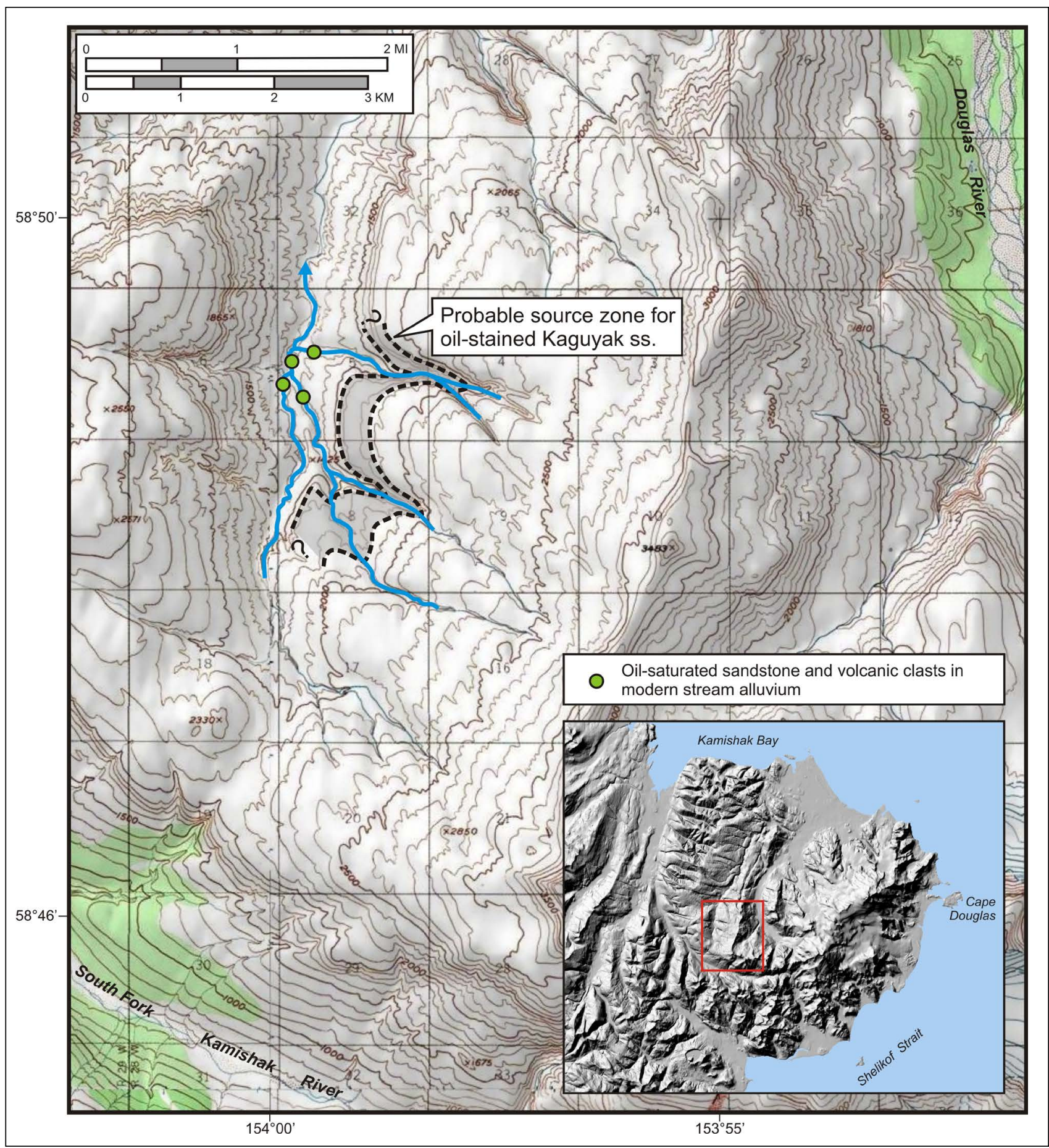

Figure 29. Location map of unnamed tributary of the Douglas River in the Kamishak Hills (see fig. 25 for location and geologic map context). Green dots indicate locations where oil-saturated cobbles and boulders were discovered in modern stream gravel. Gray-shaded area indicates likely source region for these clasts. 

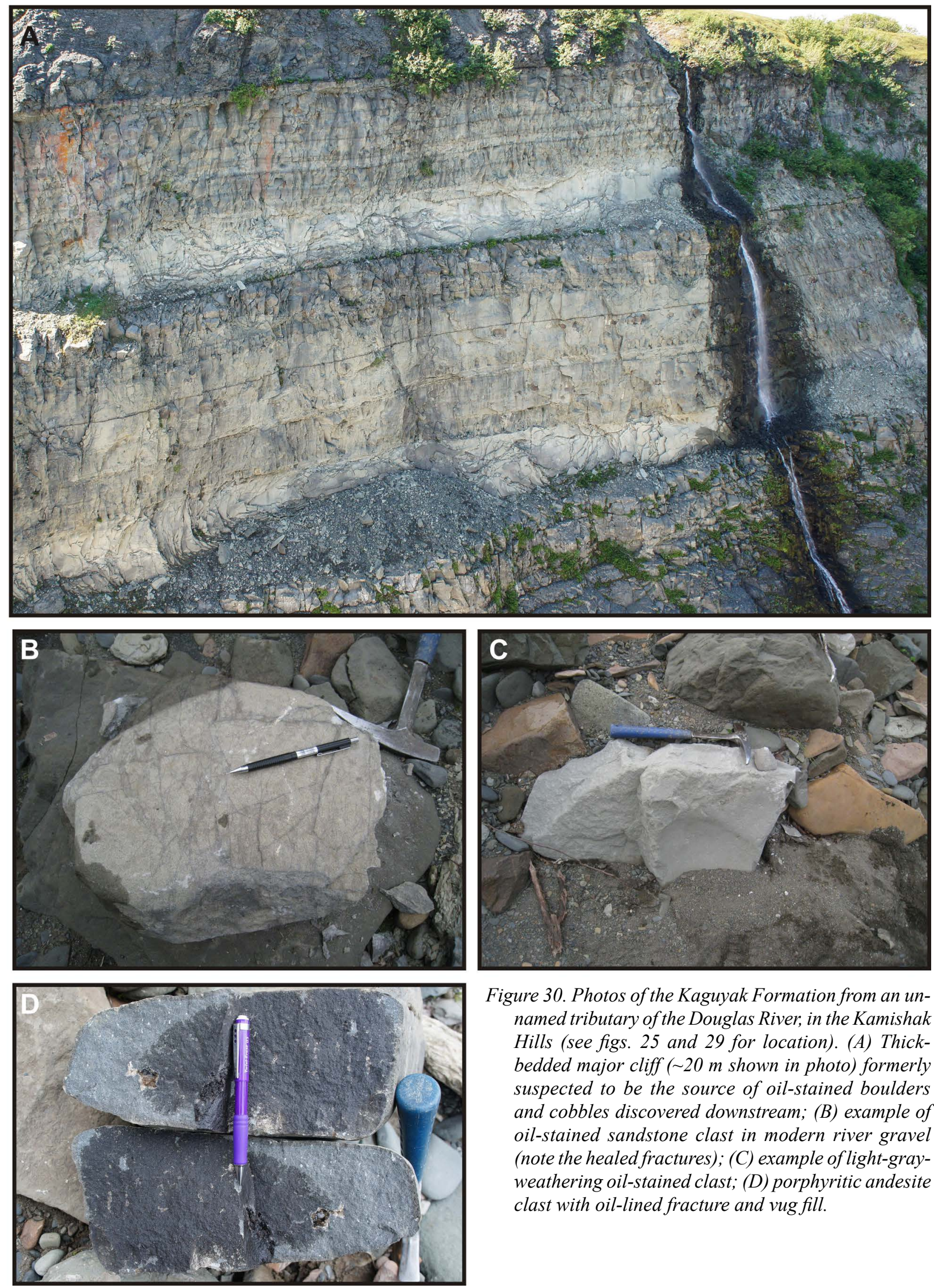

Figure 30. Photos of the Kaguyak Formation from an unnamed tributary of the Douglas River, in the Kamishak Hills (see figs. 25 and 29 for location). (A) Thickbedded major cliff ( $20 \mathrm{~m}$ shown in photo) formerly suspected to be the source of oil-stained boulders and cobbles discovered downstream; (B) example of oil-stained sandstone clast in modern river gravel (note the healed fractures); (C) example of light-grayweathering oil-stained clast; (D) porphyritic andesite clast with oil-lined fracture and vug fill. 